\title{
Sources of pollutants and environmental factors protection in the meat processing industry
}

\author{
Ovidiu Tița ${ }^{1 *}$, Adelina Maria Constantinescu ${ }^{1}$, and Mihaela Adriana Tița ${ }^{1}$ \\ ${ }^{1}$ University "Lucian Blaga” of Sibiu, Department of Agricultural Sciences and Food Engineering, 7-9 \\ Ioan Ratiu, Sibiu, Romania
}

\begin{abstract}
The production activity in the food industry involves the passage of stages of the technological process through which the raw materials are transformed into semi-finished products or finished products destined for food consumption. Their processing involves the occurrence of waste at certain operations of technological processes. These wastes can cause major environmental problems if they are not properly processed and neutralized. The study is about the smoking section of cold meats and meat specialities. The smoke required for the smoking process is produced by a generator. The resulting smoke is ventilated into the atmosphere. The sampling of air-flue gases was achieved at the level of the exhaust pipe. In the chemical composition of the smoke, about 300 known chemicals have been identified, and the most dangerous compounds identified were aromatic polycyclic hydrocarbons, especially 3,4-benzpyrene. This has resulted in an analysis of the technological conditions in which can be obtained the best results regarding the creation of safe and quality products in the conditions of using environmentally friendly working methods.
\end{abstract}

\section{Introduction}

The variation in the production, distribution and consumption of food has led to the appearance of exorbitant quantities of food waste worldwide. The continuous production of waste and the migration of the inhabitants from the rural to the urban environment are determining factors. Researchers predict that about $68 \%$ of the planet's population will live in the urban area by 2050 . Thus only about $30 \%$ of the population will supply huge quantities of fruits, vegetables and meat products for them and urbanites [1]. The production activity in the food industry involves the passage of stages of the technological process through which the raw materials are transformed into semi-finished products or finished products destined for food consumption. Their processing involves the occurrence of waste at certain operations of technological processes. These wastes can cause major environmental problems if they are not properly processed and neutralized. Preventing food waste from the factory could significantly contribute to reducing climate change and increasing energy efficiency without further effort [2]. About $40 \%$ of food waste in industrialized countries comes from retail and consumption, which is the equivalent of total net food production in Sub-Saharan Africa [1].

* Corresponding author: ovidiu.tita@ulbsibiu.ro 
The study is about the smoking section of cold meats and meat specialities. One of the most popular techniques for preserving meat and meat products is smoking [3]. Smoked meat products are very popular worldwide because they are easy to preserve and have a unique taste due to the smoke used [4]. Smoking can be defined as the process of penetrating meat products with volatile compounds resulting from burning the wood. Smoking gives the meat a drying effect, gives the desired taste, highlights the colour of the meat and also delays the alteration caused by the microbial invasion [5]. Two basic phenomena can be distinguished in the smoking process: saturation of the meat surface with the components of the smoke and the physicochemical processes, which take place in most of the product and on its surface, resulting in changes in the mechanical properties, colour and gloss of the surface [6]. However, smoked products are harmful to health due to the presence of formaldehyde (FA) and polycyclic aromatic hydrocarbons. The FA content in some meat products could be around $125 \mathrm{mg} / \mathrm{kg}$ wet weight [4]. There are more than 300 compounds found in the burning smoke of firewood, and the most present are phenols, acids and carbonyls. For health reasons for consumers, the smoke was purified by eliminating harmful compounds thus resulting in liquid form smoke [3]. Smoke in liquid form is obtained by pyrolysis at 400 degrees Celsius and contains $4.13 \%$ phenols, $11.3 \%$ carbonyl and 10.2\% acids [7]. Liquid smoking has several advantages over traditional smoking techniques, in terms of ease of application, speed, product uniformity, good characteristics of the final product, as well as reducing the danger of separation of polycyclic aromatic hydrocarbons [8].

The purpose of smoking is to conserve food by exposing it to smoke from burnt wood. The smoking section of cold meat and meat specialities consists of 3 smoking cells. Each cell is equipped with a burner to produce the steam needed to boil the products before smoking. The smoke required for the smoking process is produced in the smoke generator. The fire is softened to maximize the smoke produced and to avoid the open flame. The air is blown through the small oven and transports the smoke to the smoking room where the product is placed. The smoke existing in the room is ventilated in the atmosphere. The sampling of air-flue gases was achieved at the level of the exhaust pipe.

Order 462/1993 of the MAPPM establishes emission limit values (ELV). According to the Order 756/1997 of MAPPM, the intervention threshold represents the exceedance of the ELV, and the alert threshold represents $70 \%$ of the ELV. When the concentrations of one or more pollutants from atmospheric emissions exceed the intervention thresholds, it is considered to have an impact on the air. When the concentrations of one or more pollutants exceed the alert thresholds but are below the intervention thresholds, it is considered that there is a potential impact on the air.

Table 1. Limit values of pollutants emitted into the atmosphere from technological processes

\begin{tabular}{|c|c|c|c|c|}
\hline \multirow[b]{2}{*}{ Substance } & \multirow[b]{2}{*}{ Class } & \multirow[b]{2}{*}{ Mass flow } & \multicolumn{2}{|c|}{ Concentration } \\
\hline & & & $\begin{array}{c}\text { ELV } \\
\text { Order } 462 / 93\end{array}$ & $\begin{array}{c}\text { ELV } \\
\text { Order 756/97 }\end{array}$ \\
\hline Sulfur oxides $\left(\mathrm{SO}_{2}\right)$ & 4 & $5000(\mathrm{~g} / \mathrm{h})$ & 500 & 350 \\
\hline Nitrogen oxides $\left(\mathrm{NO}_{2}\right)$ & 4 & $5000(\mathrm{~g} / \mathrm{h})$ & 500 & 350 \\
\hline Carbon monoxide $(\mathrm{CO})$ & \multicolumn{2}{|c|}{ Has no norms } & & \\
\hline
\end{tabular}




\begin{tabular}{|c|c|c|c|c|}
\hline Suspended powders & - & $\geq 0,5 \mathrm{Kg} / \mathrm{h}$ & 50 & 35 \\
\hline Total organic carbon & 3 & $\geq 0,3 \mathrm{Kg} / \mathrm{h}$ & 150 & 105 \\
\hline
\end{tabular}

\section{Materials and methods}

A sampling of combustion air gases, suspended powders, organic compounds expressed in total organic carbon was performed at the exhaust pipe of each smoking cell.

\subsection{Smoking cell number 1}

The samples were taken both from the level of the burner pipe and the level of the smoking cell pipe.

a. Steam burner smoking cell number 1 - technological process

Table 2. Description of steam burner smoking cell number 1 - technological process

\begin{tabular}{|c|c|c|}
\hline \multicolumn{2}{|c|}{ Parameters } & Description / Values \\
\hline \multicolumn{2}{|c|}{ Used fuel } & Natural gases \\
\hline \multirow{6}{*}{ Source parameters } & Height $[\mathrm{m}]$ & 10 \\
\hline & Section $[\mathrm{sqm}]$ & 0.031 \\
\hline & Speed effluent [m/s] & 8.55 \\
\hline & Effluent flow [mc /h] & 920 \\
\hline & Effluent temperature $\left[{ }^{\circ} \mathrm{C}\right]$ & 134 \\
\hline & Environment temperature $\left[{ }^{\circ} \mathrm{C}\right]$ & 5 \\
\hline \multicolumn{2}{|c|}{ Whole pollutants } & $\begin{array}{c}\mathrm{SO} 2, \mathrm{NO} 2, \mathrm{CO}, \text { powders in } \\
\text { suspension }\end{array}$ \\
\hline
\end{tabular}

\section{b. Smoking cell - technological process}

The evacuation of the smoke from the smoking cell is done through an exhaust system, having the following parameters: 
Table 3. Description of the smoking cell - technological process

\begin{tabular}{|l|c|c|}
\hline \multirow{2}{*}{} & Parameters & Description / Values \\
\hline \multirow{3}{*}{ Source parameters } & Height $[\mathrm{m}]$ & 10 \\
\cline { 2 - 3 } & Section $[\mathrm{sqm}]$ & 0.07 \\
\cline { 2 - 3 } & Speed effluent $[\mathrm{m} / \mathrm{s}]$ & 2.2 \\
\cline { 2 - 3 } & Effluent flow $[\mathrm{mc} / \mathrm{h}]$ & 550 \\
\cline { 2 - 3 } & Effluent temperature $\left[{ }^{\circ} \mathrm{C}\right]$ & 20 \\
\hline \multirow{2}{*}{ Whole pollutants } & $\begin{array}{c}\text { Organic compounds expressed } \\
\text { in total organic carbon, } \\
\text { powders in suspension }\end{array}$ \\
\hline
\end{tabular}

\subsection{Smoking cell number 2}

A sampling of combustion air gases, suspended powders, organic compounds expressed in total organic carbon was performed at the exhaust pipe of each smoking cell.

\section{a. Steam burner smoking cell number 2 - technological process}

Table 4. Description of steam burner smoking cell number 2 - technological process

\begin{tabular}{|c|c|c|}
\hline \multicolumn{2}{|c|}{ Parameters } & Description / Values \\
\hline \multicolumn{2}{|c|}{ Used fuel } & Natural gases \\
\hline \multirow{4}{*}{ Source parameters } & Height $[\mathrm{m}]$ & 10.5 \\
\cline { 2 - 4 } & Section $[\mathrm{sqm}]$ & 0.031 \\
\cline { 2 - 4 } & Speed effluent $[\mathrm{m} / \mathrm{s}]$ & 7.65 \\
\cline { 2 - 4 } & Effluent flow $[\mathrm{mc} / \mathrm{h}]$ & 850 \\
\cline { 2 - 4 } & Effluent temperature $\left[{ }^{\circ} \mathrm{C}\right]$ & 149 \\
\cline { 2 - 4 } & Environment temperature $\left[{ }^{\circ} \mathrm{C}\right]$ & 5 \\
\hline \multirow{2}{*}{ Whole pollutants } & $\begin{array}{c}\mathrm{SO} 2, \mathrm{NO} 2, \mathrm{CO}, \text { powders in } \\
\text { suspension }\end{array}$ \\
\hline
\end{tabular}

\section{b. Smoking cell - technological process}

The evacuation of the smoke from the smoking cell is done through an exhaust system, having the following parameters: 
Table 5. Description of the smoking cell - technological process

\begin{tabular}{|l|c|c|}
\hline \multirow{2}{*}{} & Parameters & Description / Values \\
\cline { 2 - 3 } & Height $[\mathrm{m}]$ & 10.5 \\
\cline { 2 - 3 } Source parameters & Section $[\mathrm{sqm}]$ & 0.07 \\
\cline { 2 - 3 } & Speed effluent $[\mathrm{m} / \mathrm{s}]$ & 2.0 \\
\cline { 2 - 3 } & Effluent flow $[\mathrm{mc} / \mathrm{h}]$ & 500 \\
\cline { 2 - 3 } & Effluent temperature $\left[{ }^{\circ} \mathrm{C}\right]$ & 19 \\
\hline \multirow{2}{*}{ Whole pollutants } & $\begin{array}{c}\text { Organic compounds expressed } \\
\text { in total organic carbon, } \\
\text { powders in suspension }\end{array}$ \\
\hline
\end{tabular}

\subsection{Smoking cell number 3}

A sampling of combustion air gases, suspended powders, organic compounds expressed in total organic carbon was performed at the exhaust pipe of each smoking cell.

\section{a. Steam burner smoking cell number 3 - technological process}

Table 6. Description of steam burner smoking cell number 3 - technological process

\begin{tabular}{|c|c|c|}
\hline \multicolumn{2}{|c|}{ Parameters } & Description / Values \\
\hline \multirow{2}{*}{ Used fuel } & Natural gases \\
\hline \multirow{4}{*}{ Source parameters } & Height $[\mathrm{m}]$ & 10.5 \\
\cline { 2 - 4 } & Section $[\mathrm{sqm}]$ & 0.031 \\
\cline { 2 - 4 } & Speed effluent $[\mathrm{m} / \mathrm{s}]$ & 8.15 \\
\cline { 2 - 4 } & Effluent flow $[\mathrm{mc} / \mathrm{h}]$ & 910 \\
\cline { 2 - 4 } & Effluent temperature $\left[{ }^{\circ} \mathrm{C}\right]$ & 108 \\
\cline { 2 - 4 } & Environment temperature $\left[{ }^{\circ} \mathrm{C}\right]$ & $\begin{array}{c}\mathrm{SO} 2, \mathrm{NO} 2, \mathrm{CO}, \text { powders in } \\
\text { suspension }\end{array}$ \\
\hline
\end{tabular}

\section{b. Smoking cell - technological process}

The evacuation of the smoke from the smoking cell is done through an exhaust system, having the following parameters: 
Table 7. Description of the smoking cell - technological process

\begin{tabular}{|l|c|c|}
\hline \multirow{2}{*}{} & Parameters & Description / Values \\
\cline { 2 - 3 } & Height $[\mathrm{m}]$ & 10.5 \\
\cline { 2 - 3 } Source parameters & Section $[\mathrm{sqm}]$ & 0.031 \\
\cline { 2 - 3 } & Speed effluent $[\mathrm{m} / \mathrm{s}]$ & 3.1 \\
\cline { 2 - 3 } & Effluent flow $[\mathrm{mc} / \mathrm{h}]$ & 345 \\
\cline { 2 - 3 } & Effluent temperature $\left[{ }^{\circ} \mathrm{C}\right]$ & 22 \\
\hline \multirow{2}{*}{ Whole pollutants } & $\begin{array}{c}\text { Organic compounds expressed } \\
\text { in total organic carbon, } \\
\text { powders in suspension }\end{array}$ \\
\hline
\end{tabular}

\section{Results and discussions}

\subsection{Smoking cell number 1}

The results obtained from the sampling, both from the level of the burner pipe and from the level of the smoking cell pipe are presented in the tables below.

a. Steam burner smoking cell number 1 - technological process

Table 8. The measured level of pollutant concentrations from the steam burner smoking cell number 1

\begin{tabular}{|c|c|c|c|c|}
\hline \multirow{2}{*}{ Source } & \multicolumn{4}{|c|}{ Concentrations (mg / Nmc) } \\
\cline { 2 - 5 } & $\mathbf{S O}_{2}$ & $\mathbf{N O}_{2}$ & $\mathbf{C O}$ & Powders \\
\hline \multirow{4}{*}{$\begin{array}{c}\text { Burner emission } \\
\text { basket }\end{array}$} & $\mathrm{BDL}$ & 123.9 & 88.2 & 0.23 \\
\cline { 2 - 5 } & $\mathrm{BDL}$ & 114.45 & 79.8 & 0.39 \\
\cline { 2 - 5 } & $\mathrm{BDL}$ & 108.15 & 74.55 & 0.33 \\
\hline \multirow{2}{*}{$\begin{array}{c}\text { Average } \\
\text { concentration }\end{array}$} & $\mathrm{BDL}$ & 133.35 & 97.65 & 0.26 \\
\hline
\end{tabular}

Legend:

$\mathrm{SO}_{2}$ - Sulphur dioxide; $\mathrm{NO}_{2}$ - Nitrogen dioxide; $\mathrm{CO}$ - Carbon monoxide; $\mathrm{BDL}$ - below the detection limit 
According to table 8, the measured values of sulphur dioxide are below the detection limit of the measuring device. The maximum measured value of nitrogen dioxide is $133.35 \mathrm{mg} /$ $\mathrm{Nmc}$, and the average value is $119.96 \mathrm{mg} / \mathrm{Nmc}$. The maximum mass flow of $\mathrm{NO}_{2}$ measured is $122.68 \mathrm{~g} / \mathrm{h}$. The maximum measured value of carbon monoxide is $97.65 \mathrm{mg} /$ $\mathrm{Nmc}$ and the average value is $85.05 \mathrm{mg} / \mathrm{Nmc}$. The maximum mass flow measured by $\mathrm{CO}$ is $89.83 \mathrm{~g} / \mathrm{h}$. The maximum measured value of powders is $0.39 \mathrm{mg} / \mathrm{Nmc}$ and the average value is $0.30 \mathrm{mg} / \mathrm{Nmc}$. The maximum mass flow measured for powders is $0.36 \mathrm{~g} / \mathrm{h}$.

The measured level of pollutant emissions, as a result of the technological process of steam production, for all the indicators studied: it is below the alert thresholds - Order 756/97 and it is part of ELV- Order 462/93.

\section{b. Smoking cell-technological process}

Table 9. The level of the identified organic compounds expressed in total organic carbon from the emissions resulting from the technological process of smoked cold meats - cell number 1

\begin{tabular}{|c|c|c|c|c|c|}
\hline No. & $\begin{array}{c}\text { The identified } \\
\text { compound } \\
\text { (formula })\end{array}$ & $\begin{array}{c}\text { Molecular } \\
\text { mass }\end{array}$ & $\begin{array}{c}\text { \% carbon } \\
\text { from } \\
\text { molecular } \\
\text { mass }\end{array}$ & $\begin{array}{c}\text { The number of } \\
\text { substances in } \\
\text { the mixture } \\
(\boldsymbol{\mu g})\end{array}$ & $\begin{array}{c}\text { Total organic } \\
\text { carbon } \\
(\boldsymbol{\mu g})\end{array}$ \\
\hline 1 & $\mathrm{C}_{20} \mathrm{H}_{42} \mathrm{O}$ & 298 & & 18 & 14.5 \\
\hline 2 & $\mathrm{C}_{12} \mathrm{H}_{26}$ & 170 & 80.54 & 47.2 & 39.98 \\
\hline 3 & $\mathrm{C}_{7} \mathrm{H}_{8}$ & 92 & 84.71 & 7.35 & 7.61 \\
\hline 4 & $\mathrm{C}_{5} \mathrm{H}_{4} \mathrm{O}_{2}$ & 96 & 91.3 & 5.95 & 4.24 \\
\hline 5 & $\mathrm{C}_{8} \mathrm{H}_{10}$ & 106 & 75 & 5.5 & 5.31 \\
\hline & \multicolumn{5}{r}{ Total } \\
\hline
\end{tabular}

According to table number 9, the average concentration of identified organic carbon is $70.74 \mu \mathrm{g}$, respectively $0.707 \mathrm{mg} / \mathrm{Nmc}$. The average mass flow measured is $0.042 \mathrm{~g} / \mathrm{h}$. Level of total organic carbon emissions resulting from the technological process of smoked cold meat from cell number 1: it is part of the ELV - Order 462/93 and it is below the alert thresholds - Order 756/97.

Table 10. The measured level of powders in suspension emissions resulting from the technological process of smoked cold meats - cell number 1

\begin{tabular}{|c|c|c|c|}
\hline Source & Sampling time (min) & $\begin{array}{c}\text { Concentration (mg / } \\
\mathbf{m c})\end{array}$ & $\begin{array}{c}\text { Maximum mass flow } \\
\mathbf{( K g} / \mathbf{h})\end{array}$ \\
\hline Evacuation basket & 20 & 6.7 & 0.005 \\
\hline
\end{tabular}




\begin{tabular}{|l|l|r|r|}
\hline \multirow{2}{*}{} & \multirow{2}{*}{} & 5.2 \\
& & 7.0 & \multirow{2}{|c|}{} \\
\cline { 3 - 4 } & & 8.3 & \\
\hline
\end{tabular}

According to table 10, the concentrations showed values in the range $5.2-8.3 \mathrm{mg} / \mathrm{mc}$, and the maximum mass flow rate was $0.005 \mathrm{~kg} / \mathrm{h}$. The level of emissions of powders in suspension, resulting from the smoking process of cold meats: it is below the alert thresholds - Order 756/97 and it is part of the ELV - Order 462/93.

\subsection{Smoking cell number 2}

The results obtained from the sampling, both from the level of the burner pipe and from the level of the smoking cell pipe are presented in the tables below.

\section{a. Steam burner smoking cell number 2 - technological process}

Table 11. The measured level of pollutant concentrations from the steam burner smoking cell number 2

\begin{tabular}{|c|c|c|c|c|}
\hline \multirow{2}{*}{ Source } & \multicolumn{4}{|c|}{ Concentrations (mg / Nmc) } \\
\cline { 2 - 5 } & $\mathbf{S O}_{\mathbf{2}}$ & $\mathbf{N O}_{2}$ & $\mathbf{C O}$ & Powders \\
\hline \multirow{4}{*}{$\begin{array}{c}\text { Burner emission } \\
\text { basket }\end{array}$} & BDL & 114.45 & 152.25 & 0.42 \\
\cline { 2 - 5 } & BDL & 91.35 & 133.35 & 0.31 \\
\cline { 2 - 5 } & BDL & 96.6 & 142.8 & 0.33 \\
\hline \multirow{2}{*}{$\begin{array}{c}\text { Average } \\
\text { concentration }\end{array}$} & BDL & 108.15 & 145.95 & 0.36 \\
\hline
\end{tabular}

Legend:

$\mathrm{SO}_{2}$ - Sulphur dioxide; $\mathrm{NO}_{2}$ - Nitrogen dioxide; $\mathrm{CO}$ - Carbon monoxide; $\mathrm{BDL}$ - below the detection limit

According to table 11, the measured values of sulphur dioxide are below the detection limit of the measuring device. The maximum measured value of nitrogen dioxide is $114.45 \mathrm{mg} /$ $\mathrm{Nmc}$, and the average value is $102.63 \mathrm{mg} / \mathrm{Nmc}$. The maximum mass flow of $\mathrm{NO}_{2}$ measured is $97.28 \mathrm{~g} / \mathrm{h}$. The maximum measured value of carbon monoxide is $152.25 \mathrm{mg} /$ $\mathrm{Nmc}$ and the average value is $143.58 \mathrm{mg} / \mathrm{Nmc}$. The maximum mass flow measured by CO is $129.41 \mathrm{~g} / \mathrm{h}$. The maximum measured value of powders is $0.42 \mathrm{mg} / \mathrm{Nmc}$ and the 
average value is $0.35 \mathrm{mg} / \mathrm{Nmc}$. The maximum mass flow measured for powders is $0.35 \mathrm{~g}$ / h.

The measured level of pollutant emissions, as a result of the technological process of steam production, for all the indicators studied: it is below the alert thresholds - Order 756/97 and it is part of ELV- Order 462/93.

\section{b. Smoking cell - technological process}

Table 12. The level of the identified organic compounds expressed in total organic carbon from the emissions resulting from the technological process of smoked cold meats - cell number 2

\begin{tabular}{|c|l|l|l|l|l|}
\hline No. & $\begin{array}{c}\text { The identified } \\
\text { compound } \\
\text { (formula })\end{array}$ & \multicolumn{1}{|c|}{$\begin{array}{c}\text { Molecular } \\
\text { mass }\end{array}$} & $\begin{array}{c}\text { \% carbon } \\
\text { from } \\
\text { molecular } \\
\text { mass }\end{array}$ & $\begin{array}{c}\text { The number of } \\
\text { substances in } \\
\text { the mixture } \\
(\boldsymbol{\mu g})\end{array}$ & $\begin{array}{c}\text { Total organic } \\
\text { carbon } \\
(\boldsymbol{\mu g})\end{array}$ \\
\hline 1 & $\mathrm{C}_{16} \mathrm{H}_{34} \mathrm{O}$ & 242 & 79.34 & 140 & 111.08 \\
\hline 2 & $\mathrm{C}_{18} \mathrm{H}_{36}$ & 252 & 85.72 & 120 & 102.86 \\
\hline 3 & $\mathrm{C}_{19} \mathrm{H}_{40}$ & 268 & 85.07 & 20 & 17.02 \\
\hline 4 & $\mathrm{C}_{34} \mathrm{H}_{34}$ & 442 & 93.31 & 288 & 268.73 \\
\hline 5 & $\mathrm{C}_{31} \mathrm{H}_{5} \mathrm{O}$ & 442 & 84.16 & 530 & 135.39 \\
\hline 6 & $\mathrm{C}_{42} \mathrm{H}_{86}$ & 590 & 85.42 & 158.5 & 70.08 \\
\hline 7 & $\mathrm{C}_{40} \mathrm{H}_{36} \mathrm{O}_{8}$ & 644 & 74.53 & 95 & $1151093 \mu \mathrm{mg}$ \\
\hline & & & & & \\
\hline
\end{tabular}

According to table number 12 , the average concentration of identified organic carbon is $1151.93 \mu \mathrm{g}$, respectively $11.52 \mathrm{mg} / \mathrm{Nmc}$. The average mass flow measured is $0633 \mathrm{~g} / \mathrm{h}$. Level of total organic carbon emissions resulting from the technological process of smoked cold meat from cell number 1: it is part of the ELV - Order 462/93 and it is below the alert thresholds - Order 756/97.

Table 13. The measured level of powders in suspension emissions resulting from the technological process of smoked cold meats - cell number 2

\begin{tabular}{|c|c|c|c|}
\hline \multirow{2}{*}{ Source } & Sampling time (min) & $\begin{array}{c}\text { Concentration (mg / } \\
\mathbf{m c})\end{array}$ & $\begin{array}{c}\text { Maximum mass flow } \\
(\mathbf{K g} / \mathbf{h})\end{array}$ \\
\hline \multirow{2}{*}{ Evacuation basket } & 20 & 8.0 & 0.044 \\
\cline { 3 - 4 } & \multirow{2}{*}{20.7} & \\
\hline
\end{tabular}




\begin{tabular}{|l|l|l|l|}
\hline & \multirow{2}{*}{} & 5.0 & \multirow{2}{*}{} \\
\cline { 3 - 3 } & & 6.2 & \\
\hline
\end{tabular}

According to table 13, the concentrations showed values in the range $5.0-8.0 \mathrm{mg} / \mathrm{mc}$, and the maximum mass flow rate was $0.044 \mathrm{~kg} / \mathrm{h}$. The level of emissions of powders in suspension, resulting from the smoking process of cold meats: it is below the alert thresholds - Order 756/97 and it is part of the ELV - Order 462/93.

\subsection{Smoking cell number 3}

The results obtained from the sampling, both from the level of the burner pipe and from the level of the smoking cell pipe are presented in the tables below.

a. Steam burner smoking cell number 3 - technological process

Table 14. The measured level of pollutant concentrations from the steam burner smoking cell number 3

\begin{tabular}{|c|c|c|c|c|}
\hline \multirow{4}{*}{ Source } & \multicolumn{4}{|c|}{ Concentrations (mg / Nmc) } \\
\cline { 2 - 5 } & $\mathbf{S O}_{2}$ & $\mathbf{N O}_{2}$ & $\mathbf{C O}$ & Powders \\
\hline \multirow{4}{*}{$\begin{array}{c}\text { Burner emission } \\
\text { basket }\end{array}$} & $\mathrm{BDL}$ & 70.35 & 157.5 & 0.38 \\
\cline { 2 - 5 } & $\mathrm{BDL}$ & 88.2 & 189.0 & 0.48 \\
\cline { 2 - 5 } & $\mathrm{BDL}$ & 75.6 & 172.2 & 0.45 \\
\cline { 2 - 5 } & $\mathrm{BDL}$ & 73.5 & 164.85 & 0.42 \\
\hline \multirow{2}{*}{$\begin{array}{c}\text { Average } \\
\text { concentration }\end{array}$} & - & $\mathbf{7 6 . 9 1}$ & $\mathbf{1 7 0 . 8 8}$ & $\mathbf{0 . 4 3}$ \\
\hline
\end{tabular}

According to table 14, the measured values of sulphur dioxide are below the detection limit of the measuring device. The maximum measured value of nitrogen dioxide is $88.20 \mathrm{mg} /$ $\mathrm{Nmc}$, and the average value is $76.91 \mathrm{mg} / \mathrm{Nmc}$. The maximum mass flow of $\mathrm{NO}_{2}$ measured is $80.26 \mathrm{~g} / \mathrm{h}$. The maximum measured value of carbon monoxide is $189.00 \mathrm{mg} / \mathrm{Nmc}$ and the average value is $170.58 \mathrm{mg} / \mathrm{Nmc}$. The maximum mass flow measured by CO is 172.00 $\mathrm{g} / \mathrm{h}$. The maximum measured value of powders is $0.48 \mathrm{mg} / \mathrm{Nmc}$ and the average value is $0.43 \mathrm{mg} / \mathrm{Nmc}$. The maximum mass flow measured for powders is $0.43 \mathrm{~g} / \mathrm{h}$.

The measured level of pollutant emissions, as a result of the technological process of steam production, for all the indicators studied: it is below the alert thresholds - Order 756/97 and it is part of ELV-Order 462/93. 


\section{b. Smoking cell - technological process}

Table 15. The level of the identified organic compounds expressed in total organic carbon from the emissions resulting from the technological process of smoked cold meats - cell number 3

\begin{tabular}{|c|c|c|c|c|c|}
\hline No. & $\begin{array}{c}\text { The identified } \\
\text { compound } \\
\text { ( formula })\end{array}$ & $\begin{array}{c}\text { Molecular } \\
\text { mass }\end{array}$ & $\begin{array}{c}\text { \% carbon } \\
\text { from } \\
\text { molecular } \\
\text { mass }\end{array}$ & $\begin{array}{c}\text { The number of } \\
\text { substances in } \\
\text { the mixture } \\
(\boldsymbol{\mu g})\end{array}$ & $\begin{array}{c}\text { Total organic } \\
\text { carbon } \\
(\boldsymbol{\mu g})\end{array}$ \\
\hline 1 & $\mathrm{C}_{5} \mathrm{H}_{4} \mathrm{O}_{2}$ & 96 & 62.5 & 0.2 & 0.125 \\
\hline 2 & $\mathrm{C}_{7} \mathrm{H}_{8}$ & 92 & 91.31 & 0.15 & 0.137 \\
\hline 3 & $\mathrm{C}_{12} \mathrm{H}_{26}$ & 170 & 84.71 & 1.00 & 0.847 \\
\hline 4 & $\mathrm{C}_{17} \mathrm{H}_{34} \mathrm{O}_{2}$ & 270 & 75.55 & 185.0 & 139.767 \\
\hline & \multicolumn{5}{c}{ Total } \\
\hline
\end{tabular}

According to table number 15 , the average concentration of identified organic carbon is $140.876 \mu \mathrm{g}$, respectively $1.41 \mathrm{mg} / \mathrm{Nmc}$. The average mass flow measured is $0053 \mathrm{~g} / \mathrm{h}$. Level of total organic carbon emissions resulting from the technological process of smoked cold meat from cell number 1: it is part of the ELV - Order 462/93 and it is below the alert thresholds - Order 756/97.

Table 16. The measured level of powders in suspension emissions resulting from the technological process of smoked cold meats - cell number 3

\begin{tabular}{|c|c|c|c|}
\hline \multirow{2}{*}{ Source } & \multirow{2}{*}{ Sampling time (min) } & $\begin{array}{c}\text { Concentration (mg / } \\
\mathbf{m c})\end{array}$ & $\begin{array}{c}\text { Maximum mass flow } \\
\mathbf{( K g} / \mathbf{h})\end{array}$ \\
\hline \multirow{2}{*}{ Evacuation basket } & \multirow{2}{*}{20} & 4.3 & \multirow{2}{*}{0} \\
\cline { 3 - 3 } & & 7.7 & \multirow{2}{*}{0.003} \\
\cline { 3 - 3 } & & 6.1 & \\
\cline { 3 - 4 } & & 5.7 & \\
\hline
\end{tabular}

According to table 16, the concentrations showed values in the range $4.3-7.7 \mathrm{mg} / \mathrm{mc}$, and the maximum mass flow rate was $0.003 \mathrm{~kg} / \mathrm{h}$. The level of emissions of powders in suspension, resulting from the smoking process of cold meats: it is below the alert thresholds - Order 756/97 and it is part of the ELV - Order 462/93.

\section{Conclusions}


The measurements were made in a meat processing factory in the smoking section at the 3 smoking cells. A sampling of combustion air gases, suspended powders, organic compounds expressed in total organic carbon was performed at the exhaust pipe of each smoking cell.

The cumulative level of the emissions of powders in suspension resulted from the smoking section has a value of $0.0184 \mathrm{~kg} / \mathrm{h}$, which indicates that it is below the limit imposed by Order $462 / 93(0.5 \mathrm{~kg} / \mathrm{h})$. The cumulative level of emissions of organic substances, expressed in total carbon, from the smoking section has a value of $0.0016 \mathrm{~kg} /$ $\mathrm{h}$, which indicates that it is below the limit imposed by Order $462 / 93(3 \mathrm{~kg} / \mathrm{h})$.

As a result of the investigations, it is found that the technological emissions, resulting from the combustion of methane gas in the steam burners, but also the emissions from the smoker cells, have values that are registered under the maximum limits allowed by Order $462 / 93$, not constituting in aggression factors for the average air factor. The emission level will not exceed the current limits registered in this area, as there are no additional sources compared to the existing situation.

When the concentrations of one or more pollutants in the atmospheric emissions exceed the intervention thresholds, it is considered to have an impact on the air, and when the concentrations of one or more pollutants exceed the alert thresholds but are below the intervention thresholds, it is considered that there is a potential impact on the air.

Thus, an analysis was carried out regarding the conditions from the technological point of view in which the best results can be obtained regarding the creation of safe and quality products under the conditions of using environmentally friendly working methods. It is about achieving economic development in harmony with nature through good management of the resources that nature can offer us, and people can meet the demands of the present generation without compromising the capacity of future generations to meet their own needs.

\section{References}

1. L. Truong, D. Morash, Y. Liu, A. King, Int. J. Recycl. Org. Waste Agric., Food waste in animal feed with a focus on use for broilers (2019)

2. P. Sheppard, S. Rahimifard, Resour. Conserv. Recycl., Embodied energy in preventable food manufacturing waste in the United Kingdom , 146,.549-559 (2019).

3. E. Abustam, M. I. Said, M. Yusuf, H. M. Ali, IOP Conf. Ser. Earth Environ. Sci., Effect of aging time on changes in smoke flour compounds on meatballs and fresh meat of Bali beef., 247, 17 (2019)

4. J. Li, M. Wang, Q. Liu, Y. Zhang, Z. Peng, Int. J. Food Prop., Validation of uplc method on the determination of formaldehyde in smoked meat products, 21, 1246-1256 (2018)

5. D. Bhuyan, A. Das, S. K. Laskar, D. P. Bora, S. Tamuli, M. Hazarika, Vet. World, Effect of different smoking methods on the quality of pork sausages, 11, 1712-1719 (2018)

6. A. Journal, E. Sciences, S. Publications, Am. J. Environ. Sci., Removal of Unpleasant Odorous Substances from Smoke Produced by Smoke Curing Houses Zygmunt Kowalski , Zbigniew Wzorek and Marcin Banach Faculty of Chemical Engineering and Technology, Institute of Inorganic Chemistry and Technology, Cracow University, 6, 115-123 (2010)

7. E. Abustam, M. I. Said, M. Yusuf, IOP Conf. Ser. Earth Environ. Sci., The Effect of Antioxidant Activity of Liquid Smoke in Feed Supplement Block on Meat Functional of Muscle Longissimus dorsi, 119, 1-7 (2018)

8. W. Widayat, S. N. Arifiani, N. Yaqin, A. N. Al Baarri, IOP Conf. Ser. Earth Environ. Sci., Study of utilization liquid smoke and carrageenan as a natural antibacterial in manufacturing beef meatballs, 102, 1-5 (2018) 